\title{
Histologi Usus Dan Hati Juvenil Ikan Bandeng (Chanos Chanos) Yang Diberi Pakan Berbahan Tepung Ampas Minyak Biji Kapuk (Ceiba Petandra)
}

\author{
[Histology observations on theliver and intestine oflarval milkfish (Chanos chanos) \\ supplemented by Flour Kapok Seed Oil (Ceiba petandra)]
}

\section{Kasrun Ijal', Yusnaini, La Ode Baytul Abidin, Agus Kurnia}

\author{
Program Studi Budidaya Perairan, Fakultas Perikanan dan Ilmu Kelautan Universitas Halu Oleo \\ Jl. HEA Mokodompit Kampus Bumi Tridharma Anduonohu Kendari 93232,Telp/Fax:(0401)3193782 \\ *Email korespondensi: kasrunbdpa297@gmail.com
}

\begin{abstract}
ABSTRAK
Tepung ampas minyak biji kapuk (TAMBK) mengandung protein sebesar 27,32\% sehingga dapat menjadi bahan pakan ikan, tetapi biji kapuk mengandung gossypol dan asam siklopropenat yang bersifat antinutrisi. Sehingga penggunaan tepung ini untuk mensubstitusi tepung kedelai dapat menurunkan kualitas pakan. Tujuan penelitian ini adalah untuk mengetahui dampak substitusi TK dengan TAMBK dengan dosis yang berbeda terhadap histologi usus dan hati pada juvenil ikan bandeng (Chanos chanos). Empat jenis pakan dibuat berdasarkan subtitusi tepung kedelai (TK) dengan tepung ampas minyak biji kapuk (TAMBK) yang terdiri atas :100\% TK ; 0\% TAMBK (pakan A), 75\% TK : 25\% TAMBK (pakan B), 50\% TK : 50\% TAMBK

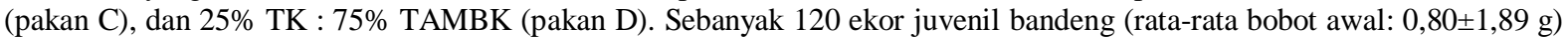
dimasukkan ke dalam 12 akuarium (10 ekor/akuarium). Selama pemeliharaan, pakan diberikan 5\% dari bobot tubuh per hari selama 30 hari. Hasil penelitian menunjukkan bahwa pemberian 25-75\% TAMBK dalam pakan menyebabkan abnormal pada organ usus yaitu vili usus menebal dan memendek, nekrosis vili serta peningkatan jumlah dan ukuran sel goblet. Jenis kerusakan pada organ hati yang tampak adalah bile stagnation atau stagnasi empedu, blood congestion dan melanomarophages centre. Kelangsungan hidup hewan uji adalah 40-60\%. Maka disarankan pemberian TAMBK dibatasi $(<25 \%)$ karena dapat merusak organ usus dan hati juvenile ikan bandeng.
\end{abstract}

Kata Kunci: tepung ampas minyak biji kapuk, histologi, juvenil bandeng.

\section{ABSTRACT}

Flour Kapok Seed Oil (TAMBK) contains $27.32 \%$ protein, so it can be used as fish feed ingredients. However, kapok seeds contain gossypol and cyclopropenic acid which are anti-nutritional. It is suspected that the use of this flour to substitute soybean flour can reduce the quality of feed. Therefore, the aim of this study was to observe the effect of TK substitution with TAMBK in feed on intestinal and liver histology in juvenile milkfish(Chanos chanos). Four types of feed were formulated based on the substitution of TK with TAMBK consisting of: 100\% TK; 0\% TAMBK (feed A), 75\% TK: 25\% TAMBK (feed B), 50\% TK: 50\% TAMBK (feed C), and 25\% TK: 75\% TAMBK (feed D). A total of 120 larval milkfish (average initial weight: $0.80 \pm$ $1.89 \mathrm{~g}$ ) were treated in 12 aquariums (10 fish/aquarium). During the rearing period, larvae was fed 5\% of body weight per day for 30 days. The results showed that the addition of 25-75\% TAMBK in feed resulted abnormalities in the intestinal organs, namely the intestinal villi being thickened and shortened, villi necrosis and an increase in the number and size of goblet cells. Meanwhile, the visible damage of liver were bile stagnation, blood congestion and melanomarophages center. The survival of fish test was $40-60 \%$. Then, it is recommended that TAMBK should be limited $(<25 \%)$ because it can damage the intestinal organs and liver of juvenile milkfish.

Keywords: Flour Kapok Seed Oil, histology, juvenile milkfish.

\section{PENDAHULUAN}

Pakan merupakan faktor yang sangat penting dalam budidaya bandeng karena menyerap $60-70 \%$ dari total biaya produksi. Pemberian pakan yang sesuai kebutuhan akan memacu pertumbuhan dan perkembangan nener bandeng sehingga produktivitasnya bisa ditingkatkan. Namun tingginya biaya pakan yang disebabkan oleh beberapa dari bahan penyusunnya masih harus diimpor seperti tepung kedelai menjadi masalah dalam penyediaan pakan. Salah satu cara yang dapat dilakukan untuk mengatasi tingginya biaya pakan adalah dengan memanfaatkan bahan pakan alternatif yang berasal dari limbah pertanian dan perkebunan yang masih mempunyai kandungan gizi cukup tinggi seperti tepung ampas minyak biji kapuk (Suriati $d k k$, 2019).

Tepung ampas minyak biji kapuk (TAMBK) merupakan produk limbah buangan hasil pembuatan minyak biji kapuk, dimana produk limbah buangan minyak biji kapuk. Ampas minyak biji kapuk mengandung air $0,21 \%$, protein kasar $27,32 \%$, lemak 5,50\%, serat kasar 24,43\% dan kadar abu 3,42\% (Fitriani, 2017). Kandungan protein yang tergolong tinggi ini menyebabkan penggunaan TAMBK dapat dipertimbangkan untuk mensubstitusi tepung kedelai dalam pakan. Kendala penggunaan TAMBK untuk menjadi 
bahan pakan menggantikan tepung kedelai (TK) adalah TAMBK mengandung zat antinutrisi berupa gossypol dan asam siklopropenat (Agus, 2008). Menurut Hasan $d k k$ (2013), kandungan zat gossypol dan asam siklopropenat dalam bahan pakan dapat berdampak terhadap penurunan aktivitas enzim amilase dan protease dalam saluran pencernaan sehingga menurunkan tingkat kecernaan pakan.

Penelitian tentang pemberian pakan berbahan biji kapuk pada udang vaname telah dilaporkan sebelumnya oleh (Muskita $d k k$, 2012) bahwa pemberian pakan tersebut tetap dapat menunjang pertumbuhan udang vaname namun menyebabkan kerusakan hepatopankreas.Penggunaan bahan pakan yang mengandung zat antinutrisi pada ikan diduga akan menyebabkan gangguan pada kinerja organ usus pada proses penyerapan nutrisi. Gangguan organ hati juga diduga akan terpicu oleh penggunaan bahan pakan yang bersifat toksik. Oleh karena itu, penelitian ini ditujukan secara khusus untuk mengetahui dampak penggunaan subtitusi tepung kedelai dengan tepung ampas minyak biji kapuk terhadap histopatologi usus dan hati pada juvenil ikan bandeng.

\section{BAHAN DAN METODE}

Penelitian ini dilaksanakan pada bulan Agustus sampai September 2020. Pemeliharaan nener bandeng bertempat di Laboratorium Unit Teknologi Pembenihan dan Produksi, Fakultas Perikanan dan Ilmu Kelautan (FPIK), Universitas Halu Oleo. Sedangkan histopatologi dilakukan di Jurusan Budidaya Perairan FPIK, Institut Pertanian Bogor.

\section{Persiapan Wadah Penelitian}

Penelitian ini menggunakan Rancangan Acak Lengkap (RAL), terdiri dari 4 perlakuan dengan 3 kali ulangan sehingga digunakan 12 unit akuarium. Akuarium yang digunakan berukuran $60 \times 50 \times 40 \mathrm{~cm}$ dan diisi air laut sebanyak $70 \%$ dari volume akuarium dengan salinitas 15 ppt. Akuarium yang digunakan dilengkapi dengan sistem resirkulasi dan ditambahkan aerasi.

\section{Pakan Uji}

Pakan uji menggunakan bahan tepung ampas minyak biji kapuk hasil fermentasi dari biji kapuk yang diperoleh dari Kecamatan Pandaan Kabupaten Pasuruan Jawa Timur. Tahapan fermentasi meliputi penyediaan bahan baku yang telah dibersihkan, lalu ditiriskan selanjutkan dilakukan fermentasi, dengan mencampurkan tepung bungkil biji kapuk yang telah dicuci lalu ditiriskan dengan ragi tape, kemudian disimpan dalam wadah yang tertutup rapat selama kurang lebih 3-5 hari (Mochtar, 2018).

Pakan uji yang digunakan pada penelitian ini adalah pakan buatan yang berbentuk pelet dengan kadar protein 38\%. Pakan uji disusun dengan rincian persentase Perlakuan A: $100 \%$ TK dan 0\% TAMBK, Perlakuan B: $75 \%$ TK dan 25\% TAMBK, Perlakuan C: $50 \%$ TK dan 50\% TAMBK, dan Perlakuan D: 25\% TK dan $75 \%$ TAMBK. Formulasi pakan dan bahanbahan yang digunakan pada penelitian ini dapat dilihat pada Tabel 1 .

\section{Pemeliharaan Ikan Uji}

Pemeliharaan nener bandeng (bobot awal $=0,80-1,89 \mathrm{~g}$ ) dilaksanakan selama 30 hari. Sebelum pemeliharaan terlebih dahulu nener bandeng diadaptasikan dengan kondisi penelitian selama satu minggu. Pemberian pakan uji diberikan sebanyak 2 kali sehari pada pukul 08.00 dan 16.00 WITA. Pakan yang tidak habis dikonsumsi oleh ikan uji disipon pada pagi hari. Pergantian air dilakukan setiap hari sebanyak $30 \%$.

\section{Histologi Ikan Uji}

Prosedur histologi dilakukan dengan modifikasi prosedur Presnel dan Schreibman (1997). Organ hati dan usus diambil kemudian difiksasi dalam larutan Bouin 10\% selama 70 jam. Sampel didehidrasi dalam larutan etanol mulai dari $70 \%, 80 \%$, 90\%, dan $100 \%$. Sampel kemudian dibersihkan dengan xylol, disematkan paraffin, diiris menggunakan microtome dengan ketebalan $5 \mu \mathrm{m}$, dan diwarnai hematoxylineosin.

\section{Kualitas air}

Sebagai data penunjang maka dilakukan pengamatan dan pengukuran variabel kualitas air diantaranya dapat dilihat pada Tabel 2.

\section{Variabel yang Diamati}

\section{Histologi Usus dan Hati}

Mengamati perubahan yang terjadi pada jaringan dan sel pada usus dan hati ikan yang telah diberi pakan berbahan tepung ampas minyak biji kapuk dibandingkan dengan perlakuan kontrol/hewan uji tanpa pemberian 
Media Akuatika : Jurnal Ilmiah Jurusan Budidaya Perairan. 2021. 6(3): 126-134.

pakan berbahan biji kapuk. Pengambilan sampel dilakukan setelah pemeliharaan selama 30 hari dan pengamatan histopatologi jaringan hati dan usus, pada hewan uji diambil 3 ekor setiap perlakuan.

\section{Tingkat Kelangsungan Hidup}

Tingkat kelangsungan hidup rata-rata dihitung berdasarkan bobot tubuh dengan mengunakan rumus (Asdari $d k k ., 2011$ ).

$$
\mathrm{SR}=\frac{\mathrm{Nt}}{\mathrm{No}} \times 100 \%
$$

Dimana : SR = Kelangsungan Hidup $(\%) ;$ No = Jumlah ikan awal penelitian (Ekor); Nt = Jumlah ikan di akhir penelitian (ekor).

\section{Analisis Data}

Tingkat kelangsungan hidup dianalisis menggunakan analisis ragam (ANOVA) dengan taraf kepercayaan $95 \%$ dengan bantuan program SPSS Versi 16,0. Pengamatan tingkat kerusakan jaringan hati dan usus dijelaskan secara deskriptif.

Tabel 1. Formulasi pakan beserta bahan-bahan yang digunakan

\begin{tabular}{lllll}
\hline \multicolumn{1}{c}{ Bahan Baku } & \multicolumn{4}{c}{ Berat Bahan yang digunakan (g) } \\
\hline Perlakuan & A & B & C & D \\
\hline Tepung Ikan Peperek & 22 & 22 & 22 & 22 \\
Tepung Kepala Udang & 22 & 22 & 22 & 22 \\
Tepung Kedelai & 25 & 18.75 & 12.5 & 6.25 \\
Tepung Ampas Minyak biji kapuk & 0 & 6.25 & 12.5 & 18.75 \\
Tepung Jagung & 10 & 10 & 10 & 10 \\
Tepung Dedak Halus & 10 & 10 & 10 & 10 \\
Tepung Tapioka & 5.5 & 5.5 & 5.5 & 5.5 \\
Tepung Sagu & 3 & 3 & 3 & 3 \\
Minyak Ikan & 0.5 & 0.5 & 0.5 & 0.5 \\
Minyak Jagung & 0.5 & 0.5 & 0.5 & 0.5 \\
MinyakCumi & 0.5 & 0.5 & 0.5 & 0.5 \\
Cr $_{2} \mathrm{O}_{3}$ & 0.5 & 0.5 & 0.5 & 0.5 \\
Top Mix & 0.5 & 0.5 & 0.5 & 0.5 \\
\hline Total & $\mathbf{1 0 0}$ & $\mathbf{1 0 0}$ & $\mathbf{1 0 0}$ & $\mathbf{1 0 0}$ \\
\hline
\end{tabular}

Tabel 2. Parameter kualitas air yang diukur selama penelitian

\begin{tabular}{llll}
\hline No & \multicolumn{1}{c}{ Parameter } & \multicolumn{1}{c}{ Alat } & \multicolumn{1}{c}{ Waktu pengukuran } \\
\hline 1. & Suhu air $\left({ }^{\circ} \mathrm{C}\right)$ & Thermometer & Setiap hari \\
2. & Salinitas $(\mathrm{ppt})$ & Handrefraktometer & 2 kali (awal dan akhir penelitian) \\
3. & Nilai $\mathrm{pH}$ & Kertas $\mathrm{pH}$ & 2 kali (awal dan akhir penelitian) \\
4. & DO $(\mathrm{mg} / \mathrm{L})$ & DO-meter & 2 kali (awal dan akhir penelitian) \\
5. & Amonia $(\mathrm{ml} / \mathrm{L})$ & Spektrofotometer & 2 kali (awal dan akhir penelitian) \\
\hline
\end{tabular}

\section{HASIL}

\section{Histologi Usus Juvenil Bandeng}

Hasil pengamatan histopatologi usus juvenil ikan bandeng yang diberi perlakuan pakan berbahan tepung ampas minyak biji kapuk dapat dilihat pada Gambar 1. Histopatologi usus perlakuan $25 \%$ TAMBK menunjukkan lipatan usus/vili yang menjadi tebal dan memendek, pada perlakuan $50 \%$ TAMBK tampak gejala yang identik dengan perlakuan $25 \%$ TAMBK namun disertai nekrosis vili (anak panah hitam). Pada perlakuan
75\% TAMBK tampak peningkatan jumlah dan ukuran sel goblet (anak panah biru).

\section{Histologi Hati Nener Bandeng}

Hasil pengamatan histopatologi hati ikan bandeng yang diberi perlakuan pakan berbahan tepung ampas minyak biji kapuk dapat dilihat pada Gambar 2. Histopatologi pada hati juvenil ikan bandeng perlakuan kontrol menunjukkan jaringan hati ikan bandeng pada keadaan normal atau tanpa dampak pemberian TAMBK. Histopatologi hati ikan perlakuan 25\% TAMBK menunjukkan terjadi kerusakan berupa bile 
Media Akuatika : Jurnal Ilmiah Jurusan Budidaya Perairan. 2021. 6(3): 126-134.

stagnation (bs), perlakuan 50\% TAMBK juga terlihat adanya kerusakan yaitu bile stagnation (bs) dengan intensitas lebih banyak dibandingkan dengan perlakuan $25 \%$ TAMBK. Sedangkan pada perlakuan $75 \%$ TAMBK tampak kerusakan jaringan yang terjadi seperti bile stagnation (bs) dan blood congestion (bc) yang jumlahnya lebih banyak daripada perlakuan $25 \%$ dan $75 \%$ serta tampak melanomacrophages centre $(\mathrm{mmc})$.

\section{Kelangsungan Hidup Nener Bandeng}

Tingkat kelangsungan hidup juvenil ikan bandeng tertinggi didapatkan pada perlakuan kontrol (tanpa pemberian TAMBK) yaitu $60 \%$, kemudian masing masing diikuti perlakuan pakan $25 \%$ dan $50 \%$ TAMB $\mathrm{K}$ sebesar $53,33 \%$, serta respon yang terendah terdapat pada perlakuan $75 \%$ TAMBK yaitu $40 \%$ (Gambar 3). Hasil analisis ragam menunjukan bahwa pemberian pakan uji tidak memberikan

pengaruh nyata $(\mathrm{P}>0.05)$ terhadap tingkat kelangsungan hidup juvenil ikan bandeng

\section{Kualitas Air}

Hasil pengukuran kualitas air Selama penelitian dapat dilihat pada Tabel 4 .

Tabel 4. Hasil Pengukuran Kualitas Air Selama Pemeliharaan.

\begin{tabular}{|c|c|c|}
\hline Parameter & $\begin{array}{c}\text { Hasil } \\
\text { pengukuran }\end{array}$ & Pembanding \\
\hline Suhu $\left({ }^{\circ} \mathrm{C}\right)$ & $26-27^{\circ} \mathrm{C}$ & $\begin{array}{l}26-27^{\circ} \mathrm{C} \\
\text { (Suriati,2019) }\end{array}$ \\
\hline $\begin{array}{l}\text { Salinitas } \\
\text { (ppt) }\end{array}$ & 15 & $\begin{array}{l}10-35 \\
2009)\end{array}$ \\
\hline $\mathrm{pH}$ & $6-7$ & $\begin{array}{l}\text { 6,5-9 (Raswin, } \\
2003)\end{array}$ \\
\hline DO (mg/L) & 4,9 & $\begin{array}{l}>3 \\
2003)\end{array}$ \\
\hline $\begin{array}{l}\text { Amonia } \\
(\mathrm{mg} / \mathrm{L})\end{array}$ & 0,024 & $\begin{array}{l}<0,1 \text { (Raswin, } \\
2003 \text { ) }\end{array}$ \\
\hline
\end{tabular}
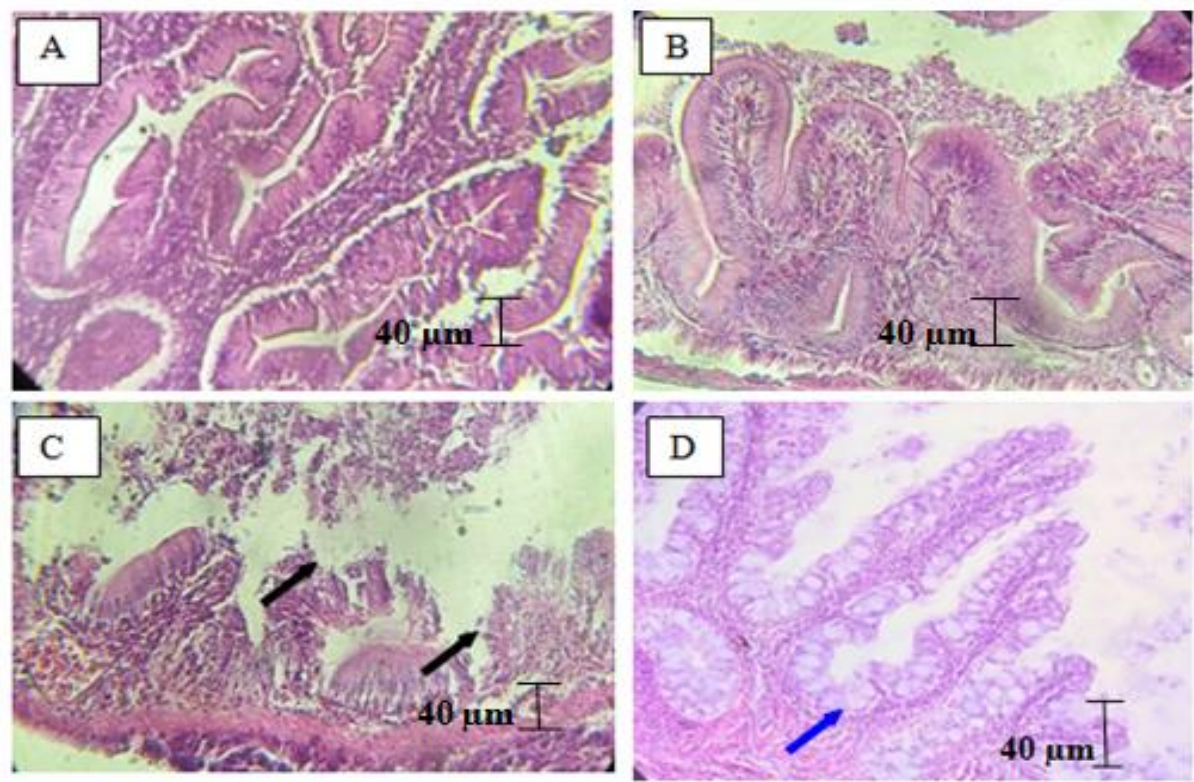

Gambar 1. Histopatologi usus bandeng. Perlakuan A (100\% Tepung Kedelai dan 0\% Tepung Ampas Minyak Biji Kapuk); Perlakuan B (75\% Tepung Kedelai dan 25\% Tepung Ampas Minyak Biji Kapuk); Perlakuan C (50\% Tepung Kedelai dan 50\% Tepung Ampas Minyak Biji Kapuk); Perlakuan D (25\% Tepung Kedelai dan 75\% Tepung Ampas Minyak Biji Kapuk). 

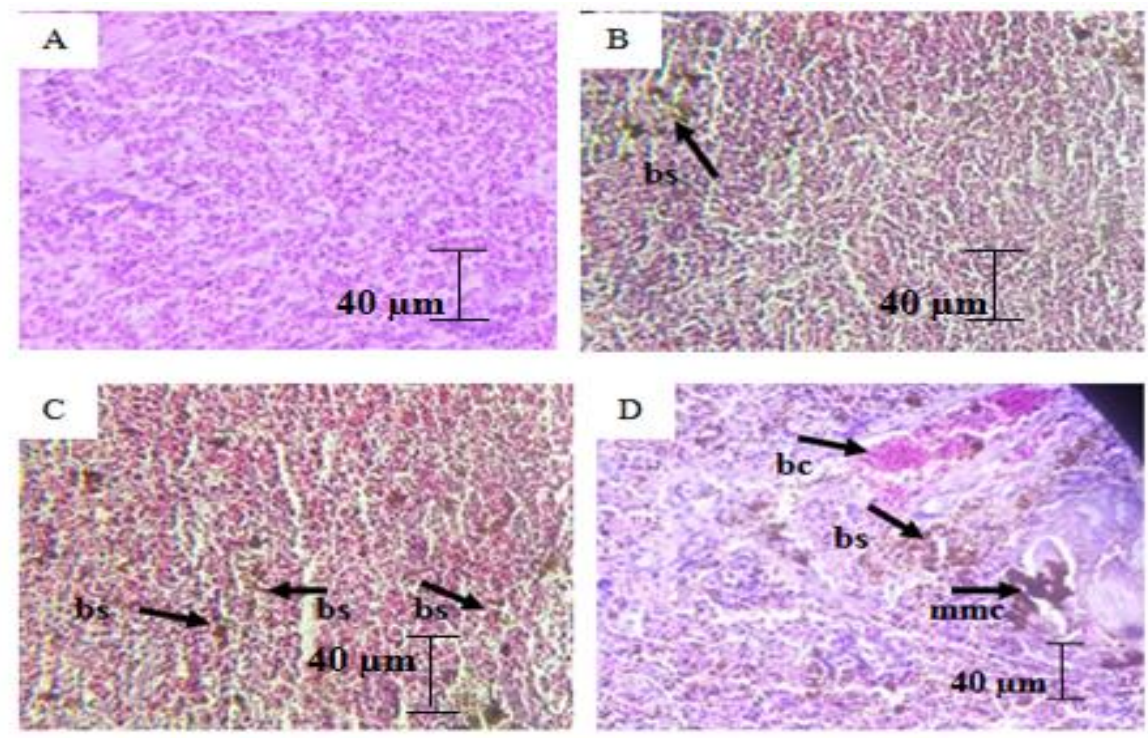

Gambar 2. Histopatologi hati bandeng Perlakuan A (100\% Tepung Kedelai dan 0\% Tepung Ampas Minyak Biji Kapuk); Perlakuan B (75\% Tepung Kedelai dan 25\% Tepung Ampas Minyak Biji Kapuk); Perlakuan C (50\% Tepung Kedelai dan 50\% Tepung Ampas Minyak Biji Kapuk); Perlakuan D (25\% Tepung Kedelai dan 75\% Tepung Ampas Minyak Biji Kapuk).

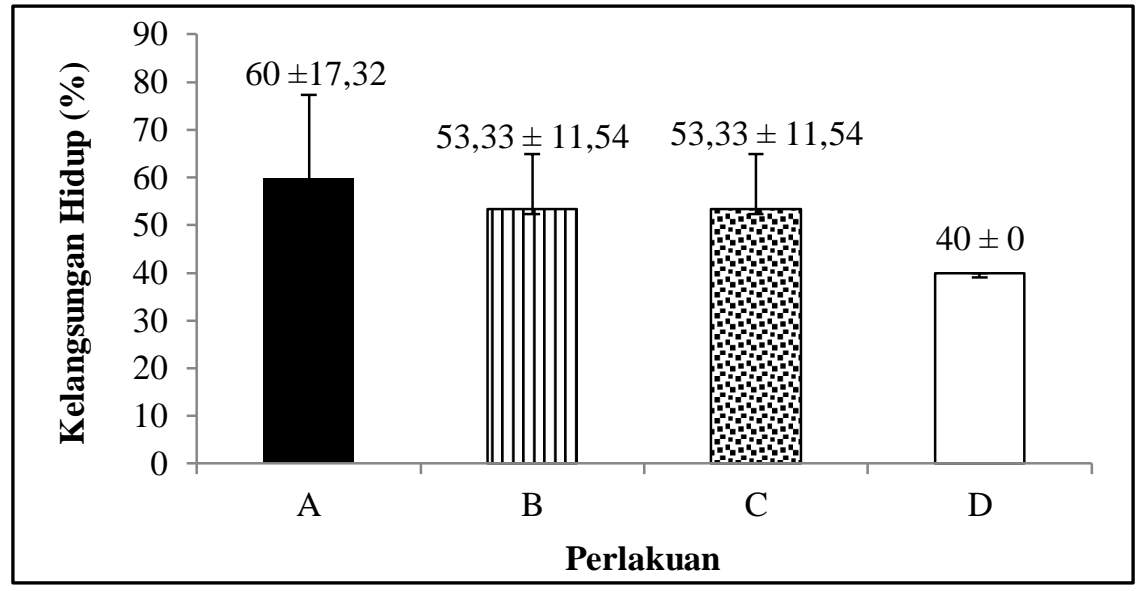

Gambar 3. Tingkat kelangsungan hidup nener ikan bandeng (C.chanos), Perlakuan A (100\% TK dan 0\% TAMBK); Perlakuan B (75\% TK dan 25\% TAMBK); Perlakuan C (50\% TK dan 50\% TAMBK); Perlakuan D (25\% TK dan $75 \%$ TAMBK).

\section{PEMBAHASAN}

\section{Histopatologi Usus}

Histopatologi usus dilakukan untuk mengetahui tingkat kerusakan jaringan usus akibat pemberian pakan yang mengandung bahan antinutrisi. Pengamatan mikroteknik pada level jaringan juga dilakukan sebagai penanda untuk mengetahui efek toksik suatu bahan pada perairan (Zhahrah dkk., 2016; Emiyarti, et al., 2020). Hasil pengamatan histopatologi usus menunjukkan bahwa pemberian pakan yang mengandung tepung ampas minyak biji kapuk berdampak terhadap perubahan ananatomi usus. Pada perlakuan 25\% dan 50\% TAMBK menunjukkan terdapat perubahanan anatomi usus yaitu lipatan usus (vili) tampak menjadi tebal dan memendek. Namun pada perlakuan 50\% TAMBK, kerusakan jaringan usus disertai oleh nekrosis lipatan usus. Kondisi abnormal lainnya tampak pada hasil pengamatan perlakuan $75 \%$ TAMBK yang menunjukkan bertambahnya jumlah dan pembesaran ukuran sel goblet. Berdasarkan hasil tersebut dapat diketahui bahwa perlakuan pemberian pakan tepung ampas minyak biji kapuk menyebabkan inflamasi atau peradangan pada usus. Kondisi serupa telah dilaporkan oleh Brugman (2016) bahwa inflamasi pada usus menyebabkan penebalan lipatan usus, peningkatan jumlah dan 
perubahan ukuran sel goblet yang membesar serta peningkatan produksi mukus. Fleming et al. (2010) juga melaporkan bahwa inflamasi pada usus ikan dapat menyebabkan hilangnya lipatan usus, lumen usus membesar, serta peningkatan jumlah sel goblet. Lipatan usus yang menjadi tebal dan memendek diduga dapat berdampak terhadap aktifitas penyerapan nutrisi dalam usus sebab kontak antara permukaan usus dengan nutrisi menjadi berkurang. Nekrosis pada lipatan usus juga berdampak terhadap penurunan fungsi usus untuk menyerap nutrisi dalam pakan.

Peningkatan jumlah bahan tepung ampas minyak biji kapuk menyebabkan peningkatan jumlah toksik dalam pakan tersebut. Peningkatan zat toksik tersebut menyebabkan peningkatan inflamasi pada usus. Proteksi usus terhadap zat toksik tersebut menyebabkan terjadi peningkatan jumlah dan membesarnya ukuran sel goblet pada perlakuan 75\% TAMBK. Hal tersebut berhubungan dengan kebutuhan sekresi mucus pada permukaan usus. Raji dan Norouzi (2010) menjelaskan bahwa peningkatan jumlah sel goblet pada usus bagian distal bertujuan untuk meningkatkan jumlah sekresi mukus yang berguna sebagai perlindungan usus dari zat asam dan lubrikasi untuk proses defikasi. Hal tersebut juga sesuai dengan pernyataan Andini $d k k$, (2017) bahwa mukus yang berada pada saluran pencernaan berfungsi dalam memproteksi permukaan usus terhadap kerusakan dan iritasi.

\section{Histopatologi Hati}

Histopatologi hati ikan uji yang diberi pakan berbahan tepung ampas minyak biji kapuk menunjukkan kerusakan jaringan hati berupa bile stagnation, blood congestion dan melanomacrophages centre.

Bile stagnation atau stagnasi empedu menurut Biuki et al. (2013) ditandai oleh butiran kuning kecoklatan di dalam sitoplasma hepatosit yang merupakan sisa cairan empedu. Stagnasi empedu terjadi pada perlakuan $25 \%$ dan perlakuan 50\% TAMBK tetapi terlihat lebih dominan pada perlakuan 50\% TAMBK. Hal ini diduga karena peningkatan konsentrasi tepung ampas pada perlakuan 50\% TAMBK menyebabkan zat toksik juga meningkat sehingga memicu peningkatan kinerja organ hati. Peningkatan kinerja organ hati yang didukung oleh empedu menyebabkan sebagian cairan empedu mengalami stagnasi pada jaringan hati. Hal ini sesuai dengan pernyataan Biuki et al. (2013), bahwa stagnasi empedu merupakan indikasi gangguan pada metabolisme hati, serta intensitas perubahan histologis dipengaruhi oleh lamanya waktu pemaparan dan konsentrasi pencemaran. Selanjutnya Muskita (2012), menjelaskan bahwa peningkatan pemberian pakan yang mengandung tepung biji kapuk dapat mengakibatkan kerusakan hepatopankreas juvenile udang.

Blood congestion pada jaringan hati ditandai oleh sel darah yang terkonsentrasi pada pembuluh darah sehingga tampak dilatasi (pelebaran) pembuluh darah. Kongesti menurut Wikiandy (2013) adalah peningkatan volume darah pada pembuluh darah yang menyebabkan pembuluh darah membengkak akibat sirkulasi darah yang melambat. Pemberian pakan yang mengandung tepung ampas minyak biji kapuk menyebabkan darah mengandung zat toksik. Kecepatan proses organ hati dalam membersihkan darah diduga tidak seiring dengan meningkatnya toksik dalam darah sehingga menyebabkan terjadinya penumpukan sel darah pada pembuluh darah. Blood congestion yang terjadi pada perlakuan D diduga dipengaruhi oleh peningkatan konsentrasi tepung ampas minyak biji kapuk sehingga kandungan zat toksik dalam pakan juga meningkat. Kongesti menurut Hadi dan Alwan (2012) dapat terjadi akibat paparan zat toksik logam.

Melanomacrophages centre merupakan salah satu indikator respon perlindungan diri terhadap bahan asing, yang ditandai dengan adanya bercak gelap pada jaringan hati. Hal ini sesuai dengan pernyataan Hadi dan Alwan (2012), yang menyatakan bahwa adanya MMC (melanomacrophages centre) yang ditandai oleh bercak gelap pada jaringan hati mengindikasikan respon perlindungan diri akibat paparan bahan toksik. Pengelompokkan sel yang mengandung pigmen tersebut bisa disebabkan penumpukkan pigmen dari zat besi (Fe) yang disebut dengan istilah hemosiderin. Hemosiderin juga dijumpai pada hati ikan nila karena kerusakan sel eritrosit (Emiyarti, et al., 2020) akibat paparan bahan toksik. Melanomacrophages centre ditemukan pada perlakuan $75 \%$ TAMBK karena pada perlakuan tersebut banyak mengandung tepung ampas biji kapuk sehingga kandungan zat toksik juga meningkat. Hal ini sesuai dengan pernyataan 
Hasan (2013) yang menjelaskan bahwa semakin tinggi penggunaan tepung biji kapuk dalam pakan maka kandungan gosipol yang bersifat toksik juga meningkat. Keberadaan zat toksik dalam pakan juga dapat menyebabkan ikan menjadi stres yang akan berdampak pada kerusakan jaringan. Kandungan zat toksik yang tinggi pada perlakuan $75 \%$ TAMBK menyebabkan kerusakan sel pada jaringan hati. Sel-sel hati yang telah mengalami kerusakan ini selanjutnya akan mengalami fagositosis oleh makrofag yang terkonsentrasi pada spot tertentu sehingga teridentifikasi sebagai MMC pada pengamatan histopatologi. Hal tersebut sesuai dengan pernyataan Mubarokah (2016), menjelaskan bahwa fagositosis oleh makrofag yang terkonsentrasi akan merangsang pembentukan dan peningkatan ukuran melanomakrofag dalam jaringan hati.

\section{Kelangsungan Hidup}

Kelangsungan hidup pada penelitian ini berkisar 40-60\% dimana pada perlakuan kontrol tanpa pemberian tepung ampas minyak biji kapuk menghasilkan tingkat kelangsungan hidup tertinggi yaitu $60 \%$, dan tingkat kelangsungan hidup terendah terdapat pada perlakuan $75 \%$ TAMBK yaitu 40\%. Rendahnya tingkat kelangsungan hidup pada perlakuan $75 \%$ TAMBK diduga karena peningkatan konsentrasi tepung ampas minyak biji kapuk dalam pakan sehingga kandungan zat toksik juga meningkat. Hal ini akan berdampak pada kerusakan jaringan usus dan hati sebagaimana telah dibahas sebelumnya. Peningkatan kerusakan jaringan pada organ-organ tersebut menyebabkan disfungsi organ sehingga memicu mortalitas organisme uji. Berdasarkan hasil penelitian ini juga diketahui bahwa peningkatan kandungan tepung ampas minyak biji kapuk berkorelasi terhadap peningkatan mortalitas atau penurunan tingkat kelangsungan hidup ikan. Hal ini dikemukakan juga oleh Herdiana (2017) bahwa kandungan gosipol dan asam siklopropenat dalam pakan yang mengandung bahan biji kapuk mengakibatkan tingkat kelangsungan hidup menjadi menurun sejalan dengan peningkatan jumlah tepung ampas minyak biji kapuk dalam pakan buatan. Triastini $d k k$, (2017) menyatakan bahwa peningkatan kandungan tepung bungkil biji kapuk hasil fermentasi dalam pakan mengakibatkan kelangsungan hidup juvenile udang vaname menurun. Oleh sebab itu, penggunaan tepung ampas minyak biji kapuk dalam pakan harus dibatasi agar menghasilkan kelangsungan hidup yang baik. Selanjutnya menurut Didyawati $d k k$. (2019), dalam penelitiannya dengan menggunakan pakan yang sama tidak memberikan pengaruh yang berbeda nyata terhadap tingkat kelangsungan hidup udang vaname. Sedangkan menurut Hasan $d k k$, (2013) menyatakan bahwa asam siklopropenat pada konsentrasi yang berlebih dapat menyebabkan nekrosis pada organ.

\section{Kualitas Air}

Kualitas air pada penelitian ini masih berada dalam kisaran normal untuk kehidupan nener bandeng. Hasil pengukuran suhu selama 30 hari pada media pemeliharan berkisar antara $26-27^{\circ} \mathrm{C}$, salinitas yang diperoleh $15 \mathrm{ppt}$. Hal ini sesuai dengan pernyataan Syahid et al (2006) menyatakan bahwa kisaran suhu optimal nener bandeng yaitu $26-32^{\circ} \mathrm{C}$ dan kisaran $\mathrm{pH} 15-35$ ppt. Sedangkan hasil pengukuran kualitas air berupa $\mathrm{pH}$ yaitu 7, DO 4,9 mg/L dan amoniak $0,024 \mathrm{mg} / \mathrm{L}$. Hasil pengukuran tersebut menunjukan kondisi kualitas air dalam wadah pemeliharan dalam kondisi normal. Hal ini sesuai dengan pernyataan Raswin (2003), bahwa nener bandeng dapat hidup dan tumbuh pada kisaran nilai $\mathrm{pH}$ 6,5-9 konsentrasi oksigen terlarut dalam air $>3 \mathrm{mg} / \mathrm{L}$, dan kadar amoniak tidak lebih dari $0,01 \mathrm{ppm}$.

\section{KESIMPULAN}

Pemberian tepung ampas minyak biji kapuk pada juvenil ikan bandeng yang dipelihara selama 30 hari mengalami kerusakan pada organ usus berupa lipatan vili menebal dan memendek, nekrosis vili serta peningkatan jumlah dan ukuran sel goblet dan kerusakan pada organ hati berupa bile stagnation atau stagnasi empedu, blood congestion dan melanomacrophages centre. Kelangsungan hidup pada penelitian ini berkisar $40-60 \%$.

\section{REFERENSI}

Agus, T. D. I. 2008. Pengaruh Penggunaan Bungkil Biji Kapuk (Ceiba Petandra) dalam Ransum terhadap Kecernaan Bahan Kering dan Bahan Organik pada Domba Lokal Jantan. Skripsi. Universitas Sebelas Maret. Surakarta.

Andini, D., Zainuddin., Jalaluddin M, Fitriani., Ummu B., Nuzul A dan Hamdan. 2017. 
Media Akuatika : Jurnal Ilmiah Jurusan Budidaya Perairan. 2021. 6(3): 126-134.

Sebaran Sel Goblet pada Usus Lele Lokal (Clarias batrachus). Jurnal JIMVET. Vol. 1(3):299-304. https://doi.org/10.21157/jim\%20vet..v1i3 .3295

Asdari, R., Aliyu-Paiko, M., Hashim, R., \& Ramachandran, S. (2011). Effects of different dietary lipid sources in the diet for Pangasius hypophthalmus (Sauvage, 1878) juvenile on growth performance, nutrient utilization, body indices and muscle and liver fatty acid composition. Aquaculture nutrition, 17(1), 44-53.

Biuki, A.N., Ahmad S., Mohammad S.M., Hossein Z dan Negin S. 2013. iver Histopathological Changes in Milkfish (Chanos chanos) Exposed to Petroleum Hydrocarbon Exposure. World Applied Sciences Journal. Vol 18 (9): 1315-1320.

Brugman, S. 2016. The zebrafish as a model to study intestinal inflammation. Developmental and Comparative Immunology, 64: 82-92.

Didyawati P., Muskita W.H., Hamzah M., Kurnia A. 2019. Substitusi Tepung Kedelai (Glycine max) dengan Tepung Ampas Minyak BijiKapuk (Ceiba petandra) terhadap Pertumbuhan dan Kelangsungan HidupUdang Vaname (Litopenaeus vannamei). Jurnal Media Akuatika. 4(3):93-102.

Emiyarti, Nur, I., Yusnaini, Astuti, O., Patadjai, R.P. 2020. Sublethal Toxicity Test of Mercury $(\mathrm{Hg})$ in The Flesh and Tissue of Tilapia (Oreochromis niloticus). Omni$\begin{array}{lll}\text { Akuatika, } & 16 & \text { (2): } \quad 99-107 .\end{array}$ http://dx.doi.org/10.20884/1.oa.2020.16. 2.749

Fitriani. 2017. Pertumbuhan Udang Vannamei (Litopenaeus vannamei) yang Menggunakan Pakan Kombinasi Ampas Minyak Biji Kapuk (Ceiba petandra) dan Ampas Tahu. Skripsi. Fakultas Perikanan dan Ilmu Kelautan. Universitas Halu Oleo. Kendari.

Fleming, A., Jankowski, J.,\& Goldsmith, P. 2010. In vivo analysis of gut function and disease changes in a zebrafish larvae model of inflammatory bowel disease: A feasibility study. Inflammatory Bowel Diseases, $16(7)$ : $1162-1172$. https://doi.org/10.1002/ibd.21200

Hadi, A. A., \& Alwan, S. F. (2012). Histopathological changes in gills, liver and kidney of fresh water fish, Tilapia zillii, exposed to aluminum. International Journal of Pharmacy \& Life Sciences, 3(11): 2071-2081.

Hasan, O.D.S., Harris, E., Suprayudi. M.A., Jusadi, D., Supriyono, E. 2013. Evaluasi Kecernaan Pakan, Kandungan Gossypol dan Asam Siklopropenoat Dalam Organ, dan Pertumbuhan Ikan Mas yang Diberi Formulasi Pakan dengan Kandungan Tepung Biji Kapuk Berbeda. Jurnal Riset Akuakultur, $\quad 8(1)$ : $97-107$. http://dx.doi.org/10.15578/jra.8.1.2013.9 7-107

Herdiana, R. 2017. Performa Juvenil Udang Vaname (Litopenaeus Vannamei) yang Diberi Pakan Kombinasi Ampas Minyak Biji Kapuk dan Ampas Tahu. Tesis. Universitas Halu Oleo Kendari.

Kordi. G dan Tancung, A. B. 2009. Budidaya Perairan Jilid 2. PT Citra Aditya Bakti. Bandung.

Mochtar , D.Y., Hamzah M., Muskita W.H. 2018. Pengaruh Pemberian Tepung Bungkil Biji Kapuk (Ceiba petandra) Hasil Fermentasi dalam Pakan Buatan terhadap Pertumbuhan Juvenil Ikan Bandeng (Chanos chsnos forskal) yang dipelihara Selama 60 Hari. Media Akuatika, 3(3):730-739.

Mubarokah, L., Tjahjaningsih, W., \& Sulmartiwi, L. (2016). Efek immunotoksik logam berat merkuri klorida (hgcl2) terhadap perubahan ukuran melano-makrofag ginjal ikan mas (Cyprinus carpio). Journal of Aquaculture and Fish Health, 5(3), 126133.

http://dx.doi.org/10.20473/jafh.v5i3.1133 4

Muskita W.H., Enang H., M. Agus S., dan Dedi J. 2012. Efek Pemberian Tepung Biji Kapuk (Ceiba Petandra), Hubungannya dengan Histologi Hepatopankreas Juvenil Udang Vaname (Litopenaeus Vannamei). Agriplus. Vol 22: 34-41.

Presnell, R.G.P., dan Schreibman, M.P., 1997. Human's Animal Tissue Techniques.5th Edition. Canada: Johns Hopkins University Press. pp. 173-177.

Raji, A.R. dan Norouzi E. 2010. Histological and histochemical study on the alimentary canal in walking catfish (Clarias batrachus) and piranha (Serrasalmus 
nattereri). Journal Veterinary Research, 11(3): 255-261.

Raswin M. M. 2003. Modul Pengelolaan Air Tambak. Direktorat Jenderal Pendidikan Dasar Dan Menengah Departemen Pendidikan Nasional.

Suriati., Hamzah M., Muskita W. H.. 2019. Pengaruh Pemberian TepungAmpas Minyak Biji Kapuk (Ceiba petandra) Terhadap Pertumbuhan Benih Ikan Bandeng (Chanos chanos). Media Akuatika, 4(2): 82-92.

Syahid M, A Subhan, dan Armando R. 2006. Budidaya Bandeng Organik Secara Polikultur. Jakarta. Penebar Swadaya.

Triastini, N.G.K., Muskita, W.H., Susilowati, P.E. 2017. Substitusi Tepung Kedelai (Glycine max) dengan Tepung Bungkil Biji Kapuk (Ceiba petandra) Hasil Fermentasi dalam Pakan Buatan terhadap Pertumbuhan dan Kelangsungan hidup Juvenil Udang Vaname (Litopenaeus vannamei). Jurnal Sains dan Inovasi Perikanan, $\quad 1(2)$ : 26-34. http://dx.doi.org/10.33772/jsipi.v1i2.662 5

Wikiandy, N., Rosidah, dan Titin H. 2013. Dampak Pencemaran Limbah Industri Tekstil Terhadap Kerusakan Struktur Organ Ikan yang Hidup di Daerah Aliran Sungai (Das) Citarum Bagian Hulu. Jurnal Perikanan dan Kelautan Vol. 4(3): 215-225.

Zhahrah, Z., Nur, I, Sabilu, K. 2016. Kerusakan jaringan hepatopankreas pada udang vaname(Litopenaeus vannamei) akibat paparan logam berat nikel $(\mathrm{Ni})$ secara buatan. Media Akuatika,1(2): 72-76. 